NBER WORKING PAPER SERIES

\title{
OVER-THE-COUNTER DERIVATIVES \\ AND SYSTEMIC RISK TO THE \\ GLOBAL FINANCIAL SYSTEM
}

Michael R. Darby

Working Paper No. 4801

\author{
NATIONAL BUREAU OF ECONOMIC RESEARCH \\ 1050 Massachusetts Avenue \\ Cambridge, MA 02138 \\ July 1994
}

I acknowledge very useful comments from Andreas Grunbichler, Mark Levonian, Francis Longstaff, Susan M. Phillips, and Lynne G. Zucker and research assistance from Paul J. Alapat, Christine Beckman, and Lynda J. Kim. An earlier version of this paper was presented at the Conference on International Financial Markets in North-East Asia: Assessment and Prospects, organized by the Seoul National University and Korea Development Institute, Hilton Hotel, Seoul, Korea, May 26-27, 1994. This paper is part of NBER's research programs in Asset Pricing and International Finance and Macroeconomics. Any opinions expressed are those of the author and not those of the National Bureau of Economic Research. 
NBER Working Paper \#4801

July 1994

\title{
OVER-THE-COUNTER DERIVATTVES
}

AND SYSTEMIC RISK TO THE

GLOBAL FINANCIAL SYSTEM

\begin{abstract}
Over the last decade dealing in derivative financial instruments (basically forwands, futures, options and combinations of these), particularly in the over-the-counter (OTC) derivatives market has become a central activity for major wholesale banks and financial institutions. Measured in terms of notional principal amount, OTC derivatives outstanding are near, if not greater than, US\$10 trillion, even after deduction of double-counting for intra-dealer transactions. Major new regulatory initiatives, including proposed new capital requirements, are under consideration as a means of reducing systemic risk. This paper examines the concept of systemic risk -- that failure of one firm will lead to the failure of a large number of other firms or indeed the collapse of the intemational financial system. Altemative proposed definitions are considered and integrated and the effects of OTC derivatives on these risks discussed. The key conclusion is that systemic risk has been reduced by the development of the OTC derivatives market due to shifting economic risks to those better able either to bear the risk or, in many cases, cancel it against offsetting risks. The implications of the Basle II capital proposals for systemic risk are analyzed and shown to increase this risk due to encouraging transactions which increase portfolio risks of the dealers and discouraging transactions which decrease their portfolio risk.
\end{abstract}

Michael R. Darby

Anderson Graduate School of Management

University of California, Los Angeles

Los Angeles, CA 90024-1481

and NBER 
The rapid rise of over-the-counter (OTC) derivatives to a central role in wholesale banking and finance with notional principal amounts rivaling stock market capitalization poses central policy issues for banking and financial regulation. In particular, policymakers are concerned with whether OTC derivatives have increased systemic risk of general failure of the global financial system. This paper attempts to bridge the gap between the academic literature and regulatory concerns by defining "systemic risk" rigorously and examining whether or not such risk has been increased or decreased by the advent of the OTC derivative market.

Since beginning work on what at the time seemed a somewhat esoteric theme, derivatives have become as timely as each morning's newspapers. This may point out one of the most salient features of the integrated global financial market .- the speed of change and evolution. We must always remember that evolution in the financial markets -- like in infectious viruses -- is often responsive to attempted cures. As a result, we are constantly at risk with regulatory initiatives of engendering new financial products and procedures to get around the latest rules that may pose more risk to the system than the prior practices which were the reason for the new regulations.

While new regulations may always engender unintended consequences in the international financial markets, this is particularly likely when regulations are aimed at dealing with a loosely defined concept such as systemic risk. If regulators are not sure what target they are shooting at, it should not be surprising if they hit something else.

In Section I, I first describe swaps and other derivatives, their magnitude and uses in the global financial market. Next I turn to the concept of systemic risk and the reasons 
that many officials believe that market forces cannot be relied upon to achieve appropriate self-regulation in the over-the-counter swaps and derivatives market. Section III contains an analysis of market arrangements in response to risk elements in the current lightly regulated regime. Section IV is a review and evaluation of the "Basle II" proposals for capital requirements on derivatives. Finally, I draw some conclusions on the implications of these financial instruments for the operation of the global financial market.

\section{Swaps and Derivatives}

Since the breakdown of the Bretton Woods system and the capital controls used to permit a modicum of monetary policy discretion while maintaining pegged exchange rates, the financial markets have become increasingly globally integrated. ${ }^{1}$ In part this global integration is a return to earlier norms, but to a greater extent it reflects the revolution in communication which has occurred contemporaneously.

A parallel development which has perhaps proceeded furthest in the United States is the securitization of traditional bank liabilities. As banks' traditional intermediary functions have grown less and less profitable, major financial institutions have increasingly turned to trading and underwriting activities in order to remain competitive with alternative uses of their shareholders' capital. Furthermore, governments' efforts to regulate -- and implicitly to tax -- bank assets have played a significant role in banks' increasing concentration on off-balance-sheet products. In addition, needs to strengthen balance sheets and capital pressures, from both the market and regulators, have been particularly relevant in the general movement to off-balance-sheet activities and fee-producing initiatives. Over- 
the-counter (or OTC) derivative products today are a major if not the largest source of earnings for approximately 150 of the world's largest commercial banks and securities firms which are active dealers in these markets. ${ }^{2}$

Derivatives are defined most generally to refer to a variety of bilateral contracts whose value derives from an underlying asset, reference rate, or index. Basically derivatives embody forward contracts, options, or some combination of these building blocks. ${ }^{3}$ Exchange-traded futures and options as well as derivative securities are not the focus of current regulatory concerns although they play an important role in allowing dealers to lay off net risk and discover prices of the forward and options components of OTC derivatives.

OTC derivatives are generally privately-negotiated forwards (such as forward commodity or foreign-exchange contracts, forward rate agreements [FRAs] or currency, interest-rate, commodity, or equity swaps) or privately-negotiated options (such as commodity, currency, equity, FRA, swap, and bond options, and caps, floors, and collars). From the point of view of the end users, OTC derivatives provide customized tools to manage risk, reduce transactions costs, lower financing costs, and enhance portfolio yields. ${ }^{4}$ OTC derivatives are available for longer maturities than are generally available for exchange-traded derivatives. ${ }^{5}$ These end users -- corporations, governments, institutional investors, and other financial institutions -- could accomplish much the same results by using exchange-traded futures and options and derivative securities, but only at the higher cost of establishing a sophisticated in-house unit capable of continually managing the equivalent portfolios without the benefit of only having to layoff the net exposure of a dealer portfolio. ${ }^{6}$ 
Thus the market is organized so that a relatively small number of banks and other financial institutions serve as counterparties to a large number of OTC derivative transactions and then actively manage the risks of the resulting net portfolio position. End users are able to shift important elements of risk to those wishing to either hedge an offsetting risk or more willing to hold a speculative position.

These are powerful advantages which have contributed to the rapid growth of the OTC derivatives market from about US\$1 trillion in 1987 to perhaps US\$5 to US\$10 trillion of underlying contract or notional principal amount now outstanding to end users. ${ }^{7}$ The exact amount is hard to pin down because of substantial potential double-counting of intradealer transactions, but the market is clearly huge. Table 1 presents some gross estimates of the growth of the derivatives markets over 1989-1992 broken down by nature of the underlying risk. Although inclusive of intra-dealer contracts, these data are consistent but incomplete as measures of total global amounts. ${ }^{8}$ The largest and fastest growing amount of contracts are concerned with interest rate risk. With notional amounts doubling every two years and currently of the same order of magnitude, it is not surprising that derivatives are receiving serious interest. However, the dealers' actual exposure to default is only a very small fraction of the principal amount, probably well less than US\$1 trillion even in the event of a major market break. Even with all due caveats taken, this is indeed a large and rapidly growing market.9

In Table 2, the totals in Table 1 are broken down by the type of derivative product. Forwards are the largest category because of inclusion of the traditional banking business of forward foreign exchange contracts in the GAO data. Excluding these contracts, the 
standard industry figures would place swaps in first place.

As alluded to earlier, there have also been recent horror stories as a number of end users appear to have moved from hedging risk to speculation on a scale that may have been literally inconceivable to their Boards of Directors. Surely, the best summary of the recent reports of speculative losses of such firms as Procter and Gamble was the Financial Times headline "Procter and guess what" (1994). ${ }^{10}$ Perhaps that corporation's suit against Bankers Trust will help ensure that dealers obtain their clients' Boards' of Directors authorization for use of derivatives in a form that makes the directors aware of the crucial importance of internal controls to prevent officers from taking uncontemplated speculative positions. " Needless to say objections to these transactions occur only when they result in losses, and in some cases when the losses are offset by gains on the assets whose value they were intended to hedge. ${ }^{12}$

Despite the fact that OTC derivatives provide another channel for fraud and mismanagement, they have become an essential element of the global wholesale banking industry. Banks must be able to provide these risk management and financing services to major corporate, governmental, and institutional clients or else see their business increasingly flow elsewhere. Similarly a country which establishes burdensome regulations on its banks will either see the banks move their derivatives business offshore or, failing that, become mere correspondents of the global banks capable of offering wholesale clients a full range of demanded services.

In conclusion, OTC derivatives are now a mainstream element of the global banking business. The issue for national policymakers is what that implies for their economies and 
the appropriate regulatory environment.

\section{Systemic Risk from Derivatives}

Despite the alarm with which those of us of a certain age respond to any sudden change, particularly one which favors younger colleagues, OTC derivatives have largely survived skeptical scrutiny. Looking first at the end user, derivatives provide a means to manage risk and reduce the risk-adjusted cost of capital, thus facilitating investment, economic growth, and rising living standards. It is true that they provide a new arena for fraud and mismanagement, but those activities surely will continue whether or not derivatives exist.

Considering the banks -- and other financial institutions -- which act as dealers and the regulatory agencies which supervise them, it turns out that the risks associated with derivatives are familiar ones and subject by and large to familiar solutions: market risk, credit risk, operational risk, and legal risk. The latter three types of risk have some interesting twists in this particular setting, but are basically amenable to management by existing best practices. ${ }^{13}$ For example, before entering into a transaction dealers should and generally do assess both expected and worst case exposure and post that exposure against the client's overall institutional credit limit. ${ }^{14}$ Furthermore, since end users of derivatives generally have access to the commercial paper market, they are the kind of credits which are increasingly absent from bank loan portfolios; thus the overall credit quality of the banks' exposure is generally strengthened by its derivatives operations.

Market risk for OTC derivatives is somewhat more difficult to measure than for most 
other bank balance sheet items, but there are important exceptions such as callable bonds and mortgage loans for which the borrower has the option to prepay. ${ }^{15}$ The Board of Governors of the Federal Reserve System has recently informed the U.S. Congress (1993a, p. 91) that it "believes that the greater awareness and understanding of risk and the enhanced methods of managing risks probably have reduced the likelihood of systemic problems, and will continue to do so over time as industry and supervisory practices advance." They go on to note that the devotion of "substantial resources to the development of more sophisticated risk management tools and ... increasing use of netting to reduce their credit exposures ... have had favorable spill-over effects on institutions' abilities to manage their total portfolios, not just their derivative activities." (p. 92)

Indeed in private conversations, U.S. regulators see the greatest challenge due to the growing use of derivatives to be upgrading their staff of examiners so that there are sufficient numbers competent to assess the validity of the banks' more sophisticated and safer approach to market and other risks. Federal Reserve Governor Susan M. Phillips (1994, p.2) sees the current round of rulemaking on OTC derivatives "as offering opportunities to provide bankers with incentives to adopt more widely and to refine the new risk management practices that have begun to be implemented by the leading derivatives dealers."

\section{Thinking about Systenic Risk}

The main charge remaining against OTC derivatives is that they increase systemic risk. This is the essence of the so-called "Promisel report" prepared by a Working Group of the Central Banks of the Group of Ten countries. Systemic risk is defined in the 
Promisel report as "the risk that a disruption (at a firm, in a market segment, to a settlement system etc.) causes widespread difficulties at other firms, in other market segments or in the financial system as a whole. ${ }^{116}$ Basically the fear is that derivatives will somehow increase the possibility of a general collapse of a significant part of if not the entire financial system: specifically, that firms' true financial conditions are less transparent, that risk may be substantially miscalculated for complicated instruments, that activity is concentrated in too few dealers, that market liquidity may be insufficient for management of very complex positions, and that increased volume may increase the level of settlement risk. ${ }^{17}$

Before returning to these specifics, I would first like to approach systemic risk from another, more personal point of view. In the summer before the October 1987 market crash, then-Federal Reserve Vice Chairman Manuel Johnson and I for the Treasury were made co-chairmen of a crisis contingency planning group which brought in representatives from the Securities and Exchange Commission, the Commodities Futures Trading Commission and other agencies as well. This provided valuable infrastructure when the crash occurred and more senior hands took over crisis management. At Treasury, I was principally responsible for oversight of the derivative markets during the crisis and had the opportunity to follow closely what was going on at our sister agencies as well. I must say that living through that experience, actually seeing the threat of major financial institutions being denied access to credit lines needed to cover cash flows required by hedged positions, and overcoming those threats only by Federal Reserve and Treasury officials giving assurances that the institutions were sound and in any case would not be allowed to fail 
gives me a personal sympathy for the concept of systemic risk that seems to be lacking among many academics. I believe that those who lived through that experience may be prone to require greater proof of safety than others might deem reasonable.

These concerns form the core of the following excerpt from the interim report of Treasury Under Secretary Gould, Federal Reserve Chairman Greenspan, S.E.C. Chairman Ruder, and C.F.T.C. Chairman Gramm:

The size and speed of the decline initiated by fundamental revaluation of equity values was exacerbated on October 19 by a number of factors:

-. many participants pulled back from the markets because of fear and shock -- and because of uncertainties and concerns over (i) the accuracy and timeliness of information, (ii) counter-party solvency, (iii) credit availability, and (iv) de facto, ad hoc market closures or other market disruptions.

-. the financial system came under great stress in the credit, clearing, and settlement area. ${ }^{18}$

Thus I see October 1987 as the crucible in which present regulatory concerns about systemic risk were formed. I would go further and say that the perceived failure in that episode of "portfolio insurance" to work as promised because of gapping prices, and the perception that the failed attempt to pursue dynamic hedging strategies made the situation worse, as argued by the Brady Commission, ${ }^{19}$ leaves a residual of official distrust for derivative instruments in general and dynamic hedging strategies in particular. While other reports and subsequent academic literature indicate that portfolio insurance played a lesser 
role than sketched by the Brady Commission, the influence of the Brady report on official concerns remains profound.

Recently, William J. McDonough, the President of the Federal Reserve Bank of New York, worried about "systemic risk of liquidity failure in the OTC derivatives market." He admitted that "our admonitions have a nagging quality because we have not specified a concrete approach to controlling and managing this risk." ${ }^{20}$

The impasse between some regulators' concerns and the analyses of academics and practitioners over this ill-defined concept of systemic risk thus is hardly surprising. I am reminded of the hypothesis that car seat belts increase injuries and deaths because they give drivers a sense of security that leads them to take greater risks. This is pretty much the core of the systemic risk indictment: Instead of being diffuse where risk gets absorbed by much nonfinancial capital, derivatives permit nonfinancial corporations to take on riskier fundamental positions, the risk of which is transferred to and concentrated in the financial sector. Furthermore, the quantitative types in the financial markets lack the experience and judgement to weigh appropriately the danger of pricing gaps while the senior managers they report to do not really understand the risks they are taking.

III. Market Solutions and Systemic Risk

Substantial regulatory proposals may be enacted on the basis of concerns such as just described. It is important to see what the market solutions are to the extent that these concerns can be made specific and testable. Let us now examine the specific components that underlie the systemic risk idea. 
The Group of Thirty's Systemic Issues Subcommittee, following the Promisel Report, decomposed the systemic concerns into nine categories: the size and complexity of the exposures, concentration among a relatively small number of financial institutions, reduced transparency of financial activities, illiquidity in the hedging markets, settlement risk, credit risk, the importance of unregulated market participants, market linkages, and legal risks. ${ }^{21}$ McDonough (1994, pp. 4-6) combines the more important of these into four thematic clusters:

- Instrument risks (complexity)

- Risks to institutions (size, credit risk, transparency)

o Risks to markets (illiquidity, market linkages)

- Evolution of risks (concentration)

The fourth of these is, in part, distinct from the Group of Thirty/Promisel list. The distinct idea is that risk borne by the derivative dealers is not only more concentrated but also in the aggregate larger. The increased aggregate risk is supposed to occur because the ability to shift risk at a low cost induces risk-taking in the nonfinancial sector. In essence this is the seat-belt argument, with no explanation why introduction of a risk reduction technology should not results in aggregate risks intermediate between those initially existing and those which would exist if there were no behavioral adjustment to the new technology. There are other taxonomies, but little substantively new beyond these.

Market participants have incentives to deal with these risks; so we need to examine what self-regulatory practices or institutions the market has developed to handle any or all of these concerns. This section first reviews them in terms of the Group of Thirty/Promisel 
taxonomy and then returns to the missing element added by the McDonough approach. ${ }^{22}$ Size and complexity. The size issue is real in the sense that these are clearly large enough positions that, if they were mismanaged, they could cause the failure of one of the large dealer institutions. However, the same could be said about a number of other lines of business, such as prepayable mortgages. It should be noted that actual exposure is normally only 2 or 3 percent of the notional principal amount -- say, US\$200 or US\$300 billion on US\$10 trillion. Losses on the rather rare defaults have averaged just over 3 percent of notional principal at risk for the defaulted transactions, and defaults are most likely where the counterparty is an unusually big loser.

Complexity is not nearly so significant an issue as it is made out to be. While tailored OTC derivatives cannot be directly hedged, they can always be broken down into their constituent components of forwards and options which can and should be managed at the portfolio level by hedging only the net position in each. Applying this sort of reasoning to such traditional bank products as mortgages is one of the very positive ways in which derivative risk management techniques have reduced the overall riskiness of banks.

Concentration. Because of the need for the highest credit standing and expensive talent and capital investment to be effective, the major dealers even in the United States can be counted on the fingers of two hands. Often, their derivatives business is conducted through AAA-rated subsidiaries continuously monitored by in-house representatives of the Moody's and Standard and Poors credit-rating firms. Moreover, these wholesale financial markets are truly global and no single firm has more than ten percent of the dealer activity.

On the other hand considerable risk has been shifted to these firms from other 
financial and nonfinancial corporations, and this concentration of risk could have the potential to leading to disruption of funding of the dealers' hedging activities in the hours of a major price break as lenders hold back to investigate rumors about individual dealers' creditworthiness.

Transparency. Perhaps in part as a result of this danger, the major dealers have worked closely with the Financial Accounting Standards Board to develop FASB Interpretation 39 effective this year to report current credit exposures from derivative transactions on dealer balance sheets. Clearly, ever increasing sophistication of risk management has made markto-market reporting and stress simulations standard tools for internal management and control as well. I would also note that an unhedged major underwriting of common stock was a major factor in the rumors which threatened financial flows in the October 1987 crisis; one wonders whether such a risk could have been undertaken today given current riskmanagement standards.

On the other hand, end users are not yet required to report in their financial statements on the hedges or speculative positions taken through derivative instruments. Such reporting is clearly desirable from the point of view of systemic risk, but also would help ensure that the Boards of Directors are aware of the risks that they are hedging or taking on..$^{23}$

Illiquidity. As discussed above, portfolios are managed in term of individual risk components, so liquidity need not be present for individual products so long as there is risk liquidity. However, experience during October 1987 and the September 1992 EMS crisis has taught dealers that even these increasingly deep risk component markets can gap 
substantially.

As a result of their concern about potential price gapping as well as for other normal business reasons, dealers run relatively balanced portfolios and thus have little net exposure to hedge. What remains are mostly hedged by exchange-traded options so that only minor mismatches remain to be hedged through dynamic trading strategies. These strategies are subject to loss due to gapping, but stress simulations are used to ensure that the potential losses are manageable. Thus awareness of the potential danger has led to strategies that do not rely on the absence of discrete price movements.

Settlement risk. Settlement risks exist but are relatively small compared to other areas of these institutions' business, primarily because only net payments are routinely transferred. To provide perspective: aggregate daily cash flows associated with OTC derivatives appear to amount to less than 5 percent of those for traditional foreign exchange transactions.

Credit risk. As discussed previously, existing practices for management of credit risk are directly applicable to OTC derivatives credit exposures. Further, overall systemic risk has been reduced in this area by the growth of OTC derivatives, since "bank dealers have increased the average quality and diversity of [credit] risk to which they are exposed. ${ }^{22}$

Table 3 provides the best available evidence on the credit standing of dealers' counterparties in OTC derivative contracts. Nearly all are investment grade and 78 percent are rated $\mathrm{A}$ or higher. These are precisely the borrowers which banks have lost to the commercial paper and other direct lending markets. While the effect on the overall creditworthiness of bank exposures is salutary, this should not be overemphasized: Among the seven largest U.S. bank dealers only Bankers Trust had larger credit exposure from 
derivatives than loans, and for five of the others the loan exposure was three or more times as large as the derivatives exposure. ${ }^{25}$

Market participants have endorsed the desirability of the legal and regulatory reforms that would be required to establish an international netting scheme as recommended by a high-level Working Group of the Central Banks of the Group of Ten countries in the socalled "Lamfalussy report." If these changes were made, such an entity would somewhat further reduce credit risk.

Unregulated entities. Central bankers and securities regulators sometimes express concern about the unregulated status of several major OTC derivatives dealers such as insurance company affiliates. Given the high credit standards required to compete as a dealer, this concern does not appear to have much substance beyond a universal desire for more data. Market linkages. While the OTC derivatives markets seem to be very much an element of the integrated global financial market, there is no apparent net contribution to systemic risk from this fact. A recent joint study by the U.S. Federal Reserve System, Federal Deposit Insurance Corporation, and Comptroller of the Currency concluded that "it is unlikely that the underlying markets would have performed as well as they did in [the] September [1992 EMS crisis] without the existence of related derivatives markets that enabled currency positions to be managed, albeit with some difficulty in some instruments." 26

Legal risks. While market participants appear to be cognizant of and responsive to legal risk, the U.K. local authorities case illustrates that residual systemic risk from an unforeseen legal ruling remains. Dealers have concerns about the enforceability in bankruptcy in some jurisdictions of netting agreements, particularly for cross-product exposures. 
The international regulatory groups, such as the Bank for International Settlements, the Basle Committee on Banking Supervision, and the Group of 10, are involved in a major effort to address legal risks. These efforts are likely to result ultimately in new legislation. Conclusions on Systemic Risk. This review of the Group of Thirty/Promisel laundry list of risk factors suggests that while there is some systemic risk associated with the OTC derivatives markets, they do not appear to be unusual or disproportionate to that element in other bank activities such as commercial or mortgage lending. Nonetheless, there are areas which could be improved and national and in ternational regulatory bodies are working to do so.

We are left then with McDonough's fourth point (the evolution of risks) to consider: Has aggregate risk been increased because it is now possible to manage risk so much better through derivatives?

The first question is whether or not nonfinancial risk taking has increased. Of course, reducing the cost of an activity -- including taking risks -- will increase the amount of it, but such an increase does not imply an increase in aggregate or systemic risk as an unintended by-product of growth in these markets since the cost reduction results from a risk reduction technology.

To that latter issue, I conclude that on balance there has been a decrease in systemic risk. The reason that this is true is because systemic risk at root is about failure of firms and fears of resulting failure of other firms, especially financial firms. The growth of the derivatives markets have reduced that risk through widespread cancelling of risk as well as shifting of risk to those most able to manage and bear it. 
If we look at each derivatives transaction, we see a principle of conservation of risk apparently at work -- risk can be transferred but not eliminated. But, as discussed above, dealers generally run closely balanced books, with the fundamental risk components closely balanced. Residual risk is generally laid off with other dealers or through exchange-traded options or futures. This entire process involves a great deal of cancellation of offsetting hedges placed by the end users, and that cancellation eliminates risk in the system as a whole.

This result should not be surprising. After all, most of the real economic transactions which give rise to the end users' demand for hedging involve symmetric risks of loss and gains to the parties to the transaction. In principle, those risks could be directly cancelled through appropriately constructed contingent contracts. Since the costs of negotiating such contracts are generally quite large relative to the underlying value, it makes sense for the parties instead to collect their risks and hedge them with risk specialists who can do so in a cost effective manner.

It is in just this manner that the derivatives markets promotes production and trade, and the associated risk-taking, by the end users. This is a clear channel by which financial institutions contribute to growth and development.

Note finally that growth in the OTC derivatives markets reduces a number of features that those involved in crisis management in October 1987 found troublesome: Because they are largely options-based contingent contracts, they involve thought-out positions of what should happen in case of large market price changes and thus reduce the potential for panic-motivated sales. Since the dealers' books are managed so as to be as 
close as practicable to balanced, there is relatively little need for potentially destabilizing dynamic hedging strategies. Most of these transactions are settled at fixed dates; so large cash flows are not required among the potential confusion of rumors associated with a financial crisis.

Thus, concerns about systemic threats of OTC derivatives are not sustained by this analysis of the market structure. Indeed, it appears that these instruments have contributed to reduction in the overall level of economic risk.

\section{The Basle II Proposals}

In April 1993 the Basle Committee on Banking Supervision released through its constituent Group of Ten central banks three supervisory documents addressing market risk and bank capital for banks active in the Global capital market. These proposals are seen to supplement the original Basle Capital Accord which was primarily concerned with credit risk, including credit risk on OTC derivatives.

One of these three documents, a consultative proposal entitled "The Supervisory Treatment of Market Risks," has been the subject of considerable debate. In fact, a number of observers see this "Basle II proposal" as so fatally flawed in its measurement of risk as to set up incentives for unbalanced portfolios which could result in higher probability of failure of individual institutions and significant increase in systemic risk. Obviously, that result is not the intention of the G-10 central-bank governors and the Basle Il proposals may be subject to considerable revision if the governors are convinced the current versions are flawed in concept. 
Indeed, these proposals, if substantially enacted in the G-10 countries and elsewhere, may provide an opportunity for nonadopting jurisdictions to develop as an offshore venue for the OTC derivatives business just as recent regulatory increases in transactions costs in Japan have promoted growth in exchange-traded Japanese derivatives in Singapore. To demonstrate this potential market shift, I first review the proposal and then show why its enactment would create a demand for doing business in jurisdictions which treat risk more consistently with the underlying economics.

First, the Basle II proposal establishes the principle that a bank or other financial institution's trading book is to be treated separately from the rest of the bank's business and have minimum capital requirements based on a separate set of rules. This proposal would not necessarily increase overall capital requirements for banks with significant trading activities, since moving certain bonds to the trading book would lower the capital requirements against those bonds so as to more of less than offset increased requirements against other activities.

Next, the proposal follows economic theory and market practice in separating exposure to interest rates, exchange rates, and equity prices, and in treating specific risk and general market risk differentially. ${ }^{27}$ Capital requirements for market risk are then based on a standard of 95 percent confidence intervals for historic two-week moves for the various market factors.

Despite these firm foundations, the proposal would implement risk measurement in an adding up with disallowances manner which seems to have been designed by accountants rather than economists or market practitioners. Practitioners are alarmed that depending 
on interpretation of some of the rules, capital requirements on what appears a well-balanced book could in fact be doubled.

One exception to the general dismay over the Basle II proposals is the analysis of Mark Levonian at the Federal Reserve Bank of San Francisco, who has recently done a remarkable job of defending the seemingly indefensible. Levonian (1994) interprets the Basle II capital standards as a linear approximation to the results of a more economically appropriate but administratively costly measure of risk based on the variance-covariance matrix of a bank's exposures. Specifically, Levonian shows that the Basle Il standards can be more generally interpreted as proportionate to a weighted average of a bank's long and short positions with the weights varying according to whether applied to foreign-exchange, debt, or equity positions. Levonian showed that the weights used for foreign-exchange risk would have resulted in an acceptable approximation to actual risk in the foreign-exchange markets for the few banks in the San Francisco district which had any such exposure. Levonian did not show that the other weighting schemes were sensible even within that district nor that the approximation schemes would continue to work if capital requirements were laid against positions in this way.

Formal comments have generally taken a different view on administrative costliness than bave the Basle II proposals. Commentators have generally pointed out that realistically very few banks run the kind of trading book to which the market risk proposals apply. Other banks should be exempted from regulation for those few through de minimis rules.

For the relatively few trading banks in the global financial market, the Basle II 
capital approach would at best require them to calculate a redundant measure of the risks they face, and more likely impose taxes on some, possibly fully hedged, transactions which would otherwise contribute to their profitability and at the same time provide effective subsidies to taking on market risks which would otherwise not be undertaken. Why not simply require them to do what is already in their self interest to do? That is, why not require trading banks to measure risk appropriately and then apply capital standards based on the actual risks undertaken as a result of their activities?

Once this question is asked, all the administrative practicality arguments for the building-blocks with disallowances approach disappear. Clearly, the compliance costs are lower for the regulated firms because they don't have to create a set of economically meaningless reports nor take on risks which would not be taken except in order to reduce their capital requirements. From the point of view of the regulators, the argument is made that the arithmetically simpler process of adding and subtracting is necessary because budgetary requirements limit severely the number they can hire and retain of examiners qualified to understand the more complicated, correct computation of risks. But, if the examiners for these institutions cannot understand the business well enough to audit whether the banks' internal risk management systems and controls are well designed and effectively implemented, there is little hope that they would do any good against a sophisticated effort to circumvent the Basle II proposal. Since regulators ultimately must rely on self-enforcement, compliance is far more likely if the rules are seen as reasonable and as not putting particular institutions at an unfair competitive disadvantage relative to other institutions. ${ }^{28}$ 


\section{Conclusions}

OTC derivatives are an important innovation which have contributed substantially to risk management wherever they have been available and used. As a result at the same time that the market has grown rapidly, risks faced by end users have declined. These risks have not simply been shifted to the dealers, however, as many of the risks can be cancelled in the market. Furthermore, the growing size of the market has led to the development of new risk management techniques and skills in dealer financial institutions which have had the effect of reducing their overall riskiness by managing risks which were previously not actively faced and managed.

This general reduction of risk in the system has on balance contributed to the overall reduction of systemic risk. There are several areas where further improvements are underway to ensure that balance is maintained and enhanced:

o Increased transparency of the derivatives positions in financial statements, particularly in those of end users, would reduce unfounded rumors during a crisis.

- A proposed international netting arrangement could make some further contribution to reducing credit and settlement risks.

Turning finally to the Basle II proposals on market risk, we see that these proposed regulatory changes could ultimately increase systemic risk or drive the derivatives offshore from adopting jurisdictions. The problem is not with the intentions or even analytical approach of that document, but rather with short-cuts taken where none are required. 
Arak, Marcelle, Arturo Estrella, Laurie Goodman, and Andrew Silver, "Interest Rate Swaps: An Alternative Explanation," Financial Management, Summer 1988, 17: 12-18.

Bank for International Settlenients, Report of the Committee on Interbank Netting Schemes of the Central Banks of the Group of Ten Countries, ["Lamfalussy Report"], Basle: Bank for International Settlements, November 1990.

Bank for International Settlements, Recent Developments in International Interbank Relations, Report prepared by a Working Group established by the Central Banks of the Group of Ten countries, ["Promisel Report"], Basle: Bank for International Settlements, October 1992.

Basle Committee on Banking Supervision, "The Supervisory Treatment of Market Risks," Basle, April 1993.

Becketti, Sean, "The Prepayment Risk of Mortgage-backed Securities," Federal Reserve Bank of Kansas City Economic Review, February 1989, 74: 43-57.

Bicksler, James, and Andrew H. Chen, "An Economic Analysis of Interest Rate Swaps," The Journal of Finance, July 1986, 41: 645-655.

Calla, James J., and Sidney S. Pomper, "Interest Rate Swaps: A Derivative Product for Portfolio Managenent," Joumal of Commercial Lending, June 1993, 75: 12-22.

Darby, Michael R., "The Internationalization of American Banking and Finance: Structure, Risk, and World Interest Rates," Journal of International Money and Finance, December 1986, 5: 403-428. [Reprinted in Internationalization of Banking and Finance -- Analysis and Prospects, Proceedings of the Second International Symposium on Financial Development, Seoul, Korea: Korea Federation of Banks, 1986.]

Darby, Michael R., "Real Exchange Rates and Freedom of International Trade and Capital Flows," Cato Journal, Fall 1988, 8 : 473-475.

Evans, Richard, Carol Bere, and Betsy Massar, "Derivatives Superstars: Anonymous No Longer," Global Finance, February 1994, 8(2): 39-74.

Gennotte, Gerard, and Hayne Leland, "Market Liquidity, Hedging, and Crashes," American Economic Review, December 1990, 80: 999-1021.

Global Derivatives Study Group [G-30], Derivatives: Practices and Principles, Washington, DC: The Group of Thirty, July 1993. (1993a) 
Global Derivatives Study Group [G-30], Derivatives: Practices and Principles. Appendix I: Working Papers, Washington, DC: The Group of Thirty, July 1993. (1993b)

Gumerlock, Robert, "Double Trouble," Risk, September 1993, $6(9)$.

International Swaps and Derivatives Association, Inc. [ISDA], "Consultative Proposal by the Basle Committee: Capital Adequacy for Market Risk," comment letter to the Basle Committee on Banking Supervision, December 28, 1993.

Levonian, Mark E., "Bank Capital Standards for Foreign Exchange and Other Market Risks," Federal Reserve Bank of San Francisco Economic Review, 1994, Number 1, pp. 3-18.

Litzenberger, Robert H., "Swaps: Plain and Fanciful," The Joumal of Finance, July 1992, 47: 831-850.

Longstaff, Francis A., and Eduardo S. Schwartz, "A Simple Approach to Valuing Risky Fixed and Floating Rate Debt and Determining Swap Spreads," UCLA Finance Working Paper no. 22-93, revised April 1994.

Melnik, Arie L., and Steven E. Plaut, "Currency swaps, hedging, and the exchange of collateral," Journal of International Money and Finance, October 1992, 11: 446-461.

McDonough, William J., remarks presented at the Conference on Financial Markets, sponsored by the Federal Reserve Bank of Atlanta, Coconut Grove, Florida, February 25, 1994.

Morris, Charles S., "Managing Interest Rate Risk with Interest Rate Futures," Federal Reserve Bank of Kansas City Economic Review, March 1989, 74: 3-20. (1989a)

Morris, Charles S., "Managing Stock Market Risk with Stock Index Futures," Federal Reserve Bank of Kansas City Economic Review, June 1989, 74: 3-16. (1989b)

Morris, Charles S., and Thomas J. Merfeld, "New Methods for Savings and Loans to Hedge Interest Rate Risk," Federal Reserve Bank of Kansas City Economic Review, March 1988, 73: 3-15.

Phillips, Susan M., "Derivatives and Risk Management: Challenges and Opportunities," remarks presented at the Conference on Financial Markets, sponsored by the Federal Reserve Bank of Atlanta, Coconut Grove, Florida, February 25, 1994.

"Procter and guess what," editorial, Financial Times, April 21, 1994, p. 21. 
Remolona, Eli M., "The Recent Growth of Financial Derivative Markets," Federal Reserve Bank of New York Quarterly Review, Winter 1992-93, 17: 28-43.

Schrage, Michael, "Innovation: As Derivatives Debacles Add Up, It's Time to Ask: Hedge or Risk", Los Angeles Times, May 5, 1994, pp. D1 \& D3.

Taylor, Jeffrey, and Kenneth H. Bacon, "How the Nymex Cooled MG's Oil Crisis," Wall Street Journal, April 5, 1994, pp. C1 \& C6.

U.S. Board of Governors of the Federal Reserve System, "Responses to Questions on Financial Derivatives Posed by Congressman James A. Leach, Committee on Banking, Finance, and Urban Affairs, U.S. House of Representatives," Washington: Board of Governors of the Federal Reserve System, October 6, 1993. (1993a)

U.S. Board of Governors of the Federal Reserve System, "Responses to Questions on Financial Derivatives Posed by Congressman Henry B. Gonzalez, Chairman, Committee on Banking, Finance, and Urban Affairs, U.S. House of Representatives," Washington: Board of Governors of the Federal Reserve System, October 26, 1993. (1993b)

U.S. Board of Governors of the Federal Reserve System, Federal Deposit Insurance Corporation, and Comptroller of the Currency, Derivative Product Activities of Commercial Banks, Joint study conducted in response to questions posed by Senator Riegle on derivative products, Washington: Board of Governors of the Federal Reserve System, January 27, 1993.

U.S. General Accounting Office, Financial Derivatives: Actions Needed to Protect the Financial System, Report GAO/GGD-94-133, Washington: General Accounting Office, May 1994.

U.S. Presidential Task Force on Market Mechanisms, Report, ["Brady Commission Report"], U.S. Government Printing Office: Washington, January 1988.

U.S. Working Group on Financial Markets, "Interim Report of the Working Group on Financial Markets," submitted to The President of the United States, U.S. Government Printing Office: Washington, May 1988.

Wall, Larry D., "Interest Rate Swaps in an Agency Theoretic Model with Uncertain Interest Rates," Journal of Banking and Finance, May 1989, 13: 261-270. 
1. See Darby $(1986,1988)$ for fuller arguments on these points.

2. These dealers are represented by a trade association known currently as the International Swaps and Derivatives Association and formerly as the International Swap Dealers Association (ISDA in either case). See ISDA (1993) for a current discussion of the membership. At the end of 1991, the 25 top dealers in interest rate and currency swaps comprised 19 banks, 4 securities firms, and 2 insurance companies; 14 were U.S. based and 11 from other countries (Global Derivatives Study Group [G-30] 1993a, p. 42).

3. The most comprehensive and comprehensible source on the OTC derivatives market is the Group of Thirty study, especially Global Derivatives Study Group [G-30] (1993a). I can only attempt to briefly summarize that material here.

4. Although widely accepted by practitioners who appear to know their business, the idea that swaps or other derivatives can reduce financing costs or enhance portfolio returns is controversial in the academic literature. Significant contributions to the discussion include James Bicksler and Andrew H. Chen 1986, Marcelle Arak, Arturo Estrella, Laurie Goodman, and Andrew Silver 1988, Larry D. Wall 1989, Robert H. Litzenberger 1992, and Arie L. Melnik and Steven E. Plaut 1992.

5. The availability of long maturities seems to be a particularly attractive feature to the end users. As we shall see, dealers are able to serve as counterparties in the place of a clearinghouse because they run trading books with closely matched exposures to underlying risk.

6. Writing for the Federal Reserve Bank of Kansas City, Charles S. Morris (1989a and 1989b) and Morris and Thomas J. Merfeld (1988) lay out risk-management strategies for financial institutions using exchange-traded futures and options or combinations of those instruments with interest-rate swaps.

7. Estimates vary widely depending on date and amount of netting out of double counting used. Global Derivatives Study Group [G-30] (1993a) uses ISDA data which exclude double-counting of intra-dealer transactions to estimate that swaps notional principal was US\$4.5 trillion at the end of 1991. Global Finance reported in August 1993 that the notional principal amount exceeded US\$10 trillion (Evans, Bere, and Massar 1994, p. 41). Eli M. Remolona (1992-93) reports intermediate estimates for the Federal Reserve Bank on New York. U.S. Board of Governors of the Federal Reserve System (1993b) reports a great detail of data on the derivatives activities of U.S. bank holding companies and their affiliates. 
8. These data include foreign exchange forward contracts which are generally excluded from industry estimates.

9. For example, gross credit risk for 14 major U.S. financial institutions with $\$ 6.5$ trillion on notional amount outstanding was only $\$ 114$ billion or 1.8 percent of the notional amount (U.S. General Accounting Office 1994, p. 53.)

10. The Procter and Gamble loss is currently estimated at US\$157 million. The January 1994 Metallgesellschaft AG bailout amounted to US\$1.95 billion for losses from speculating both on and off exchange in the oil market (see Taylor and Bacon 1994).

11. The House of Lords in 1991 found that the London Borough of Hammersmith and Fulham lacked the authority to undertake the swap contracts it had transacted at great loss during the 1980s. This finding resulted in: (a) most of the default losses since the inception of swap activity and (b) more fastidious concern as to whether dealers' customers were authorized to undertake the transactions which they were making.

12. In the GAO's survey -. which some observers considered a politically motivated search for horror stories to justify regulatory initiatives -- only 1 percent ( 2 respondents) reported ever filing a complaint or litigating over a derivatives transaction. In one case, a complaint to a fund's management resulted in a resolution satisfactory to the respondent and the other case resulted in litigation. (U.S. General Accounting Office 1994, p. 135.)

13. There are many private and official analyses of the internal risk management and supervisory issues which come to similar conclusions. Most follow closely the analysis in Global Derivatives Study Group [G-30] (1993a, pp. 43-52).

14. James J. Calla and Sidney S. Pomper (1993, pp. 17-19) report on how this is done at one U.S. superregional bank.

15. On the latter point, see Sean Becketti 1989.

16. Bank for International Settlements ["Promisel Report"] (1992, p. 61).

17. See Global Derivatives Study Group [G-30] 1993b, pp. 127-129.

18. U.S. Working Group on Financial Markets 1988, pp. 1-2.

19. See, for example, the indictment of portfolio insurers and their "mechanical, priceinsensitive selling" in the fourth and fifth paragraphs of the Brady Commission's Executive Summary. U.S. Presidential Task Force on Market Mechanisms 1988, p. v. The Promisel report returns to portfolio insurance "as an example of the destabilizing potential of the market linkages associated with dynamic hedging strategies." (Bank for International Settlements 1992, p. 26. Gerard Gennotte and Hayne Leland (1990) provide an academic analysis of how dynamic hedging strategies could have caused a large price drop in 1987. 
20. McDonough 1994, p. 6.

21. Global Derivatives Study Group 1993b, pp. 128-129. Although theirs is the best analysis of systemic risk of which I am aware, I believe that their reading of the Promisel Report may overstress the importance of systemic risk as seen in that document.

22. My review of the Group of Thirty/Promisel issues relies heavily on Global Derivatives Study Group 1993b and International Swaps and Derivatives Association, Inc. 1993.

23. Michael Schrage (1994) makes this point: "The greatest risk derivatives bring to the marketplace is not their complexity of volatility; it's the shadowy way in which they can be used by companies that would rather not tell the marketplace the truth about their investment intentions. The antiseptic for that infection is not more regulation; it's better and fuller disclosure."

24. Global Derivatives Study Group [G-30], 1993b, p. 135. Academic economists have done some interesting work recently on the role of credit risk in the pricing of OTC derivatives; see Francis A. Longstaff and Eduardo S. Schwartz (1994) and the references cited there.

25. U.S. General Accounting Office (1994), pp. 53-55.

26. U.S. Board of Governors of the Federal Reserve System, Federal Deposit Insurance Corporation, and Comptroller of the Currency 1993, p. 18.

27. See Robert Gumerlock (1993) for a careful analysis of the strengths and weaknesses of the proposal. The ISDA comment letter (International Swaps and Derivatives Association, Inc. 1993) is also an important piece of analysis.

28. Commenting on a draft of this paper, Mark Levonian has made two important points (a) the internal systems adopted by dealers might differ if they knew their capital requirements would be based on the indicated net risks and (b) "nobody knows as well as the insiders how to game the bank's internal systems." I think that the Lucas critique [point (a)] is wrong in this case because one cannot really bias the calculations in general unless one also knows the desired bias to be maintained in the book. Since dealers do not show any desired bias, it is hard to cook the books. I agree that insiders may try to game the internal risk control system, but in that case their supervisors have a clear reason to try to catch them before they cause disaster. Their supervisors would have little reason to do the same in the face of avoidance of capital controls. 
Table 1

Notional Amount of Derivatives outstanding

by Nature of the Underlying Risk

1989-1992

$\begin{array}{lrrrrr}\text { Underlying } & 1989 & 1990 & 1991 & 1992 & \begin{array}{r}\text { Pct. } \\ \text { Crowth }\end{array} \\ \text { Interest Rates } & 4,311 & 6,087 & 8,404 & 10,923 & 153 \\ \text { Exchange Rates } & 2,779 & 3,927 & 5,415 & 6,475 & 133 \\ \text { Equity/Commodity } & 108 & 158 & 209 & 245 & 127 \\ \text { Total outstandings } & 7,198 & 10,172 & 14,028 & 17,643 & 145\end{array}$

Amounts in billions of U.S. dollar equivalents.

Source: U.S. General Accounting office (1994), p. 35.

Notes:

a. Percentage increase from 1989 to 1992.

b. Data on individual-firm-equity-price and physical-comodityprice derivatives are especially incomplete. 
Table 2

Notional Amount of Derivatives outstanding

by Type of Derivative Product

1989-1992

$\begin{array}{lrrrrr}\text { Derivative Product } & 1989 & 1990 & 1991 & 1992 & \begin{array}{c}\text { Pct. } \\ \text { Growth }\end{array} \\ \text { Forwards } & & & & & \\ \text { Futures } & 3,034 & 4,437 & 6,061 & 7,515 & 148 \\ \text { Options } & 1,259 & 1,540 & 2,254 & 3,154 & 151 \\ \text { Swaps } & 953 & 1,305 & 1,841 & 2,263 & 137 \\ \text { Total Outstandings } & 7,198 & 10,172 & 14,028 & 17,643 & 145\end{array}$

Amounts in billions of U.S. dollar equivalents.

Source: U.S. General Accounting office (1994), p. 36.

Notes:

a. Percentage increase from 1989 to 1992 .

b. Forwards include foreign exchange, FRAs, equity and commodity forwards. 
Table 3

Credit Ratings of 200 Companies with More than $\$ 1$ Billion

in Swaps outstanding as of Year-End 1991

Credit Rating

AAA Of Aaa

$A A$ or Aa

A

Total A or Better

$\mathrm{BBB}$ or Baa

Total Investment Grade

Speculative

Unrated

Total Noninvestment Grade 29

Total All Grades
No. of

Firms

21

34

78

133

38

171

15

14

200
Notional Amts.

Outstanding

535

1,747

2,023

4,305

1,066

5,371

30

106

136

5,507

Percent

9.7

31.7

36.7

78.2

19.4

97.5

0.6

1.9

2.5

100.0

Amounts in billions of U.S. dollar equivalents.

Source: U.S. General Accounting office (1994), p. 59. 